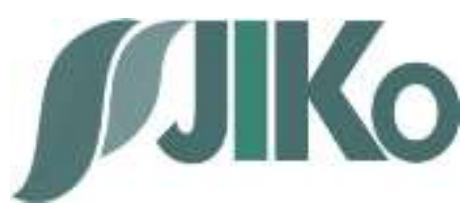

\title{
Fundamental factors of firm value: Evidence from the cement industry in Indonesia \\ Widyarti Kusumowardhani ${ }^{1}$ \\ Post Graduate Management, Universitas Muhammadiyah Malang, Indonesia ${ }^{l}$
}

Received: 21-11-2019 | Revision: 26-11-2019 | Accepted: 03-02-2020

\begin{abstract}
This study aims to analyze the factors which influence firm value. This study uses multiple regression analysis and takes data from three cement companies listed on the IDX. The results of this study concluded that companies must be efficient and keep the debt ratio to maintain the firm value.
\end{abstract}

Keywords: firm value; efficient; debt ratio

\section{Introduction}

The Investors who invest in the stock market will analyze the condition of the company to get maximum profit (Hu et al., 2018; Lee, Cho, Kwon, \& Sohn, 2019). The Investors will look for prospective companies by considering external and internal factors (Rao, Chandy, \& Prabhu, 2008; Sujoko, 2017). Internal and external investment feasibility studies are conducted to see the company's fundamental and macroeconomic conditions and those two factors complement each other (Han, Yang, \& Zhou, 2013; Jensen \& Berg, 2012; Stambaugh, Yu, \& Yuan, 2012). The investors valuation that is indicated by share price can be a measure of firm value (Wijoyo, 2018). For a company, the firm value can be an indication of investor sentiment regarding the company's performance. Therefore, the firm value that is stable and has positive progress is something that always wants to be achieved. Such conditions will have a good impact, especially on the aspect of increased funding obtained in the capital market.

A lot of macro economy factors affect firm value; one of the most discuss by scholars is the interest rate. Lettau \& Wachter (2011) suggested in their research that the interest rates are one of the factors that influence the firm value. The increasing of the interest rates will encourage people to saving. Then, the interest rates will affect the level of corporate debt. As a result, the funding received by the company will decrease and implies to slow down of company's expansion. In the end, this condition will cause a decrease in firm value. Therefore, the general increase in interest rates will break firm value (Lin, Wang, Wang, \& Yang, 2018; Made Gede Wirakusuma, 2013).

Because this research takes a company engaged in the cement industry, we also pay attention to the level of cement consumption as factors macroeconomic. National cement consumption can be interpreted as an indicator level of market's purchasing power. Beside, several degrees of the use of cement is realized every time whether it

\footnotetext{
${ }^{1}$ ciwulank@rocketmail.com
} 
increases or decreases. Improved economic growth, the market's purchasing power of cement has also increased. This condition has led to cement companies to increase their sales and gain ever-increasing profits.

Furthermore, the first firm fundamental factor that influences is level of liquidity that represented by Debt to Equity Ratio (DER). The higher level of company liquidity will have a positive influence on the firm value. Capital structure measures with total debt and debt to equity ratio are negatively related to the firm performance. Several researches recommend that firms should use more of equity than debt in financing their business activities, in as much as the value of a business can be enhanced by using debt capital (Akeem, K, Kiyanjui, \& Kayode, 2014).

Secondly, fundamental fantor which has also caught the attention of investors and scholars is Return on Equity (ROE). The research on the companies on the Indonesian Stock Exchange in the period 2006-2010 shows that ROE has a positive but not significant effect on the firm value (Rosikah et al, 2018). Although there may be differences in the literature regarding the significance of influence ROE on the firm value, in general, ROE influences the firm value (Damodaran, 2011; Manab \& Ghazali, 2013).

Another factor that might influence the firm value is Total Assets Turnover (TAT). A study of the capital structure of Romanian companies listed o the Bucharest Stock Exchange and manage the construction sector shows that TAT has an influence on leverage (Serghiescu \& Vaidean, 2014). Another study also shows that TAT has a significant positive effect on the statistic stock allocation (Dada \& Ghazali, 2016).

If in general, the previous studies discuss the factors that influence the firm value partially, this study measures the fundamental factors of macroeconomic and company economics. It aims to analyze the factors that effect the firm value comprehensively. For the implication, the result of this study can be used as reference in an effort to optimize the firm value.

\section{Research Method}

The population used in this study was companies engaged in the cement industry and listed on the Indonesia Stock Exchange in the period 2008-2015. The sample used was three cement companies, namely PT Indocement Tunggal Prakarsa Tbk, PT Holcim Indonesia Tbk, and PT Semen Gresik Tbk. Meanwhile, the data of the cement consumption was taken from dataindustri.com. This study used share prices as the measurement of the firm value and used multiple regression analysis with SPSS software.

\section{Result and Discussion}

Table 1, through the F-test, showed that simultaneously the model constructed was significant. The results of the t-test analysis in Table 2 also showed that all variables were partially significant. The results of the data analysts howed that the interest rates in the cement industry recorded on IDX in the 2008-2015 period were directly proportional to the interest rates. It means that one percent increases in the interest rates will raise share prices by IDR 956.98. Sudarsono \& Sudiyanto (2016), Karim (2015), and Buana (2014) in their research also showed that the interest rates had a positive and significant effect on share price. 
Tabel 1. F-test and coefficient of determination

\begin{tabular}{lcccc}
\hline \multicolumn{1}{c}{ Mean Square } & $\mathrm{F}$ & Sig & \multirow{2}{*}{ Durbin Watson } \\
\cline { 1 - 3 } 216973894.584 & 80.462 & 0.00 & & \\
R Square & Adjusted R Square & Standar Error & \\
\cline { 3 - 4 } 0.856 & 0.846 & 1642.133 & 0.000 \\
\hline
\end{tabular}

Tabel 2. Coefficient of regression and t-test

\begin{tabular}{lcccc}
\hline & $\begin{array}{c}\text { Unstandardized } \\
\text { Coeffisients }\end{array}$ & & \multicolumn{2}{c}{ Standardized Coefficients } \\
\hline Constant & $B$ & Std. Error & $\mathrm{t}$ & Sig \\
IR & 10304.58 & 6702.12 & 1.349 & .181 \\
CC & 956.98 & 452.70 & 2.045 & .044 \\
DE & 134.154 & 55.24 & 3.132 & .002 \\
ROE & -159.699 & 58.82 & -3.319 & .001 \\
TAT & 562.40 & 159.91 & 3,280 & .002 \\
\hline
\end{tabular}

It is in contrast to several cognate studies that show an increase in the interest rates will reduce share prices. Increasing the interest rate will reduce the present value and dividend income in the future; this condition will make the investors carry out diversification of assets (Karini, 2009). Furthermore, an interest rate that is too high will affect the value of the company's cash flow and it can even be a barrier to growth. This condition make companies to bear higher capital costs (Wismantara, 2017). On the other hand, the interest rates that are too high will also reduce purchasing power. If the company is vulnerable to the interest rates, the company's performance will undoubtedly decrease and the share price will continue to be corrected consequently.

However, this condition does not seem to be a concern if the increase in the interest rates is still within reasonable limits. Some of the researches show that the interest rates can have a positive and negative impact on the share prices. Not only the positive or negative impact but also the level of significance is also divers. Research on the companies engaged in the hospitality at IDX during the 2005-2010 period showed that the interest rates had a positive but not significant effect (Dwita, \& Rahmidani, 2012). The results of this study and several previous studies showed that even though in the theory interest rates would burden companies, reduce reduced performance and ultimately would disrupt stock prices, but several empirical studies showed that the effects were diverse and sometimes insignificant. Therefore, we conclude that a reasonable interest rate will not affect the level of stock returns.

Furthermore, we discuss about the fundamental firm factors. The DE coefficient in Table 2 shows the negative coefficient value. It is an indication that if the company's DE has been increased by one percent, then the share price will suffer a decline of IDR 159,699. The research toward 15.897 UKM in Swedia that operated in five industrial sectors during the 2009 - 2012 period negatively affected the company's performance in the terms of profitability. Because it has a higher debt ratio, it increases the agency cost and the risk of losing access to the company (Yazdanfar \& Öhman, 2015). The same thing 
applies to the large-scale companies that generally DE has a negative impact on the firm value (Akeem et al., 2014; Yazdanfar \& Öhman, 2015).

Meanwhile, ROE has a positive sign. It shows that for every one percent increase in ROE, the company's share price will increase by around IDR 562.40.

Some similar studies also show that ROE in general without regard to the field of business always has a positive effect on the firm value (Heikal, Gaddafi, \& Ummah, 2014; Rosikah et al, 2018). This is very reasonable because ROE is one indicator to assess the effectiveness of management in using equity financing to fund operations and grow the company (Halpern et al., 2013; Heikal et al., 2014).

The third internal fact is TAT; TAT has a highest coefficient. It means that if TAT rises by one percent then the share price will rise by $\mathrm{Rp} 920.68$. Some studies from various companies and countries point to TAT in general which has a positive effect on the share prices (Almazari, 2012; Serghiescu \& Văidean, 2014; Shaverdi, Heshmati, \& Ramezani, 2014; Supardi, H. Suratno, \& Suyanto, 2018). It is very easy to understand because in principle TAT is an efficiency indicator of company in generating sales (Esterlina \& Firdausi, 2017; Huda, Sinaga, \& Andati, 2015).

The results of this study illustrate that ROE and TAT factors have an influence on DE.It indicates that in addition to the company needing to maintain the debt ratio, the company also needs to maintain and improve its efficiency.If DE is compressed with $\mathrm{CC}$, it can be concluded although the trend of the cement consumption in the market is increasing excessive expansion through the debt and it also also needs to be noted.

\section{Conclusions}

This study indicates that the optimization of the firm value can be done by increasingthe efficient of the company and keep the ratio debt. Meanwhile, the company does not need to worry about the changing of the interest rate.

\section{References}

Akeem, L. B., K, E. T., Kiyanjui, M. W., \& Kayode, M. (2014). Effects of Capital Structure on Firm 's Performance : Empirical Study of Manufacturing Companies in Nigeria. Journal of Finance and Investment Analysis.

Almazari, A. A. (2012). Financial Performance Analysis of the Jordanian Arab Bank by Using the DuPont System of Financial Analysis. International Journal of Economics and Finance. https://doi.org/10.5539/ijef.v4n4p86

Dada, A. O., \& Ghazali, Z. B. (2016). The Impact of Capital Structure on Firm Performance: Empirical Evidence from Nigeria. IOSR Journal of Economics and Finance. https://doi.org/10.9790/5933-0704032330

Damodaran, A. (2011). Return on Capital (ROC), Return on Invested Capital (ROIC) and Return on Equity (ROE): Measurement and Implications. SSRN Electronic Journal. https://doi.org/10.2139/ssrn.1105499

Esterlina, P., \& Firdausi, N. N. (2017). Analisis Kinerja Keuangan Perusahaan Sebelum Dan Sesudah Merger Dan Akuisisi. Jurnal Administrasi Bisnis S1 Universitas Brawijaya.

Halpern, B. S., Klein, C. J., Brown, C. J., Beger, M., Grantham, H. S., Mangubhai, S., ... Possingham, H. P. (2013). Achieving the triple bottom line in the face of inherent 
trade-offs among social equity, economic return, and conservation. Proceedings of the National Academy of Sciences of the United States of America. https://doi.org/10.1073/pnas.1217689110

Han, Y., Yang, K., \& Zhou, G. (2013). A New Anomaly: The Cross-Sectional Profitability of Technical Analysis. Journal of Financial and Quantitative Analysis, 48(5), 1433-1461. https://doi.org/10.1017/S0022109013000586

Heikal, M., Khaddafi, M., \& Ummah, A. (2014). Influence Analysis of Return on Assets (ROA), Return on Equity (ROE), Net Profit Margin (NPM), Debt To Equity Ratio (DER), and current ratio (CR), Against Corporate Profit Growth In Automotive In Indonesia Stock Exchange. International Journal of Academic Research in Business and Social Sciences. https://doi.org/10.6007/ijarbss/v4-i12/1331

Hu, G., Hu, Y., Yang, K., Yu, Z., Sung, F., Zhang, Z., ... Miemie, Q. (2018). Deep Stock Representation Learning: From Candlestick Charts to Investment Decisions. In 2018 IEEE International Conference on Acoustics, Speech and Signal Processing (ICASSP) (pp. 2706-2710). IEEE. https://doi.org/10.1109/ICASSP.2018.8462215

Huda, G. N., Sinaga, B. M., \& Andati, T. (2015). The Influence of Corporate Financial Performance on Share Return. Indonesian Journal of Business and Entrepreneurship. https://doi.org/10.17358/ijbe.1.3.163

Jensen, J. C., \& Berg, N. (2012). Determinants of Traditional Sustainability Reporting Versus Integrated Reporting. An Institutionalist Approach. Business Strategy and the Environment, 21(5), 299-316. https://doi.org/10.1002/bse.740

Lee, T. K., Cho, J. H., Kwon, D. S., \& Sohn, S. Y. (2019). Global stock market investment strategies based on financial network indicators using machine learning techniques. Expert Systems with Applications, 117, 228-242. https://doi.org/10.1016/j.eswa.2018.09.005

Lettau, M., \& Wachter, J. A. (2011). The term structures of equity and interest rates. Journal of Financial Economics, 101(1), 90-113. https://doi.org/10.1016/j.jfineco.2011.02.014

Lin, X., Wang, C., Wang, N., \& Yang, J. (2018). Investment, Tobin's q, and interest rates. Journal of Financial Economics, 130(3), 620-640. https://doi.org/10.1016/j.jfineco.2017.05.013

Made Gede Wirakusuma, I. (2013). Pengaruh Faktor Internal Dan Eksternal Perusahaan Terhadap Audit Delay. E-Jurnal Akuntansi, 2(3), 525-543.

Manab, N. A., \& Ghazali, Z. (2013). Does Enterprise Risk Management Create Value. Journal of Advanced Management Science. https://doi.org/10.12720/joams.1.4.358-362

Rao, R. S., Chandy, R. K., \& Prabhu, J. C. (2008). The Fruits of Legitimacy:Why Some New Ventures Gain More from Innovation Than Others. Journal of Marketing, 72(4), 58-75. https://doi.org/10.1509/jmkg.72.4.58

Rosikah et al. (2018). Effects of Return on Asset, Return On Equity, Earning Per Share on Corporate Value. The International Journal of Engineering and Science (IJES. https://doi.org/10.9790/1813-0703010614

Serghiescu, L., \& Văidean, V.-L. (2014). Determinant Factors of the Capital Structure of a Firm- an Empirical Analysis. Procedia Economics and Finance. https://doi.org/10.1016/s2212-5671(14)00610-8

Shaverdi, M., Heshmati, M. R., \& Ramezani, I. (2014). Application of fuzzy AHP 
approach for financial performance evaluation of iranian petrochemical sector. In Procedia Computer Science. https://doi.org/10.1016/j.procs.2014.05.352

Stambaugh, R. F., Yu, J., \& Yuan, Y. (2012). The short of it: Investor sentiment and anomalies. Journal of Financial Economics, 104(2), 288-302. https://doi.org/10.1016/j.jfineco.2011.12.001

Sujoko, S. (2017). Pengaruh Struktur Kepemilikan, Strategi Diversifikasi, Leverage, Faktor Intern Dan Faktor Ekstern Terhadap Nilai Perusahaan (Studi Empirik Pada Perusahaan Manufaktur Dan Non Manufaktur Di Bursa Efek Jakarta). EKUITAS (Jurnal Ekonomi Dan 236. https://doi.org/10.24034/j25485024.y2007.v11.i2.2236

Supardi, H., H. Suratno, H. S., \& Suyanto, S. (2018). Pengaruh Current Ratio, Debt To Asset Ratio, Total Asset Turnover Dan Inflasi Terhadap Return On Asset. JIAFE (Jurnal Ilmiah Akuntansi Fakultas Ekonomi). https://doi.org/10.34204/jiafe.v2i2.541

Wijoyo, A. (2018). Faktor-faktor yang mempengaruhi nilai perusahaan pada perusahaan property dan real estate di bursa efek indonesia. Jurnal Ekonomi, 23(1), 48-61. https://doi.org/10.24912/je.v23i1.333

Yazdanfar, D., \& Öhman, P. (2015). Debt financing and firm performance: an empirical study based on Swedish data. Journal of Risk Finance. https://doi.org/10.1108/JRF-062014-0085 